\title{
Sosyo
}

Ekonomi

\section{Muhasebe Temelli Tahmin Modelleri Işığında, Finansal Sıkıntı ve İflasın Karşılaştırııması}

İhsan KULALI

ikulali@btk.gov.tr

\section{In the Light of Accounting Based Prediction Models, Comparatives of Financial Distress and Bankruptcy}

\begin{abstract}
More than fifty years, there have been many academic studies about financial distress. Although there is no absolute and common-shared definition of financial distress, generally prediction models have been correlated with bankruptcy. However, financial distress is not only related with bankruptcy but also different from bankruptcy in some manner. Bankruptcy can be accepted as a last step of financial distress and generally it is related with violation of the debt liabilities. In this manner, financially, it is correlated with the balance sheet more than financial distress. When it is accepted that bankruptcy is a last step of financial distress, there is no enough time for firms' manager to eliminate financial distress in the light of bankruptcy prediction model result. This situation requires building different prediction model for financial distress.
\end{abstract}

Keywords $\quad: \quad \begin{aligned} & \text { Financial Distress, Bankruptcy, Z-Score, Accounting- } \\ & \text { based Prediction Models. }\end{aligned}$

JEL Classification Codes : $\quad$ G32.

\section{Özet}

Finansal sıkıntıya yönelik çalışmalar elli yılı aşkın bir süredir yapılmaktadır. Bununla birlikte finansal sıkıntı kavramının net ve üzerinde herkesçe uzlaşılan bir tanımı olmaması nedeniyle, çalışmalar genellikle iflas tahmin modelleri ile ilişkilendirilmiştir. Finansal sıkıntı, ilgili olmakla birlikte, belirli ölçülerde iflastan ayrılmaktadır. İflas, finansal sıkıntı sürecinin son aşamasını ifade ederken çoğunlukla firmaların borç sözleşmelerine ait yükümlüklerinin yerine getirilmemesi ile ilgilidir. $\mathrm{Bu}$ anlamda iflas, finansal sıkıntıya nazaran, finansal açıdan, firmanın bilançosu ile daha çok ilişkilendirilmektedir. İflasın, finansal sıkıntının son aşamasını ifade ettiği dikkate alındığında, tahmin sonuçlarının yöneticilere finansal sıkıntının önlenmesine yönelik yeterli süreyi sağlayamaması riski bulunmaktadır. Birbirleri ile çok yakından ilgili finansal sıkıntı ve iflasın belirli ölçüde farklılaşması, tahmin modellerinde de daha farklı yaklaşımların benimsenmesi gereğini ortaya koymaktadır. 
İhsan KULALI 


\section{Giriş}

Yaşanan küresel kriz mali piyasalardaki düzenlemelerin yeterli olup olmadığı yönündeki soruların yeniden gündeme gelmesine neden olmuş ve bu durum düzenleyicilerin sermayenin hem miktar hem de kalite olarak artırılmasına yönelik yeni standartlar getirmelerine yol açmıştır. Bununla birlikte sermaye artışlarının finansal sıkıntıyı ${ }^{1}$ ne derece azalttığına yönelik kanıtlar ise oldukça azdır. Düzenleyici ve politika yapıcılar her ne kadar sermaye yeterliliğinin artırılması ve borçlanma (kaldıraç) oranlarının düşürülmesi konusunda hem fikir olmakla birlikte; "yeterli yüksekliğin ne olmas1 gerektiği" konusu hala net değildir (Buehler vd., 2009: 2-3). Finansal başarısızlığın tahmin edilmesi, ülke ekonomisi ve toplum üzerinde yarattığı sosyoekonomik sorunlar nedeniyle son derece önemlidir. Finansal başarısızlık tahmin modeli, işletme yönetim politikalarına katkı sağlamakta, kredi değerlendirmede, sorunlu kredileri tahmin etmede kullanılmakta ve yatırımcıların doğru karar vermelerine katkıda bulunmaktadır (Altaş \& Giray, 2005: 14). Bu nedenle firmaların yaşadıkları finansal sıkıntının tespitine yönelik çalışmaların önemi, krizin kaynağında tespit edilerek ekonominin geneline yayılmasına önlemek için daha da artmıştır.

Finansal sıkınt, sermaye yapıs1, yatırım politikası ve firma performans1 üzerinde etkisi olan uzun dönemli bir süreçtir (Kahl, 2002: 135). Finansal sıkıntıya yönelik uygulamaların önemi, çok sayıda çalışmada, serbest piyasa ekonomisinin en önemli yapıtaşlarından bir tanesini teşkil eden iflas kanunlarına yönelik devam eden tartışmalar ekseninde ele alınmaktadır (Suarez \& Susman, 2004: 1). Söz konusu düzenlemeler, finansal sıkıntının hangi mekanizma ile çözümleneceği ile alacaklıların hakları ve firma varlıklarının dağıtımı konularına odaklanmaktadır. Nihayetinde bu düzenlemelerin yatırımcıların sermaye temin isteklerini, firmanın sermaye yapısını ve sermaye maliyeti seçimlerini etkilediğini söylemek mümkündür. $\mathrm{Bu}$ yap1 finansal ekonomistlerin, yöneticilerin ve hukukçuların firmanın finansal sıkıntı ile nasıl baş edebileceğinin anlaşılmasının önemini artırmaktadır (Hotchkiss, 2008: 3).

Finansal sıkıntı tahmin modelleri yaklaşık 50 yıllık bir geçmişe sahiptir. Modeller, firmaların çeşitli finansal problemleri olup olmadığı veya gelecek dönem iflas edip etmeyeceğinin tahmin edilmeye çalışılmasına dayanmaktadır. Bir firmanın iflasının ekonomik sonuçları oldukça önemli ve büyüktür. Bu açıdan finansal sıkıntının tahminine yönelik modeller; girişimciler, yatırımcılar, kreditörler, denetçiler ve diğer tüm paydaşların büyük ilgisini çekmektedir. Modeller firmaların hangi olasılıklar dâhilinde sıkıntıya

1 Finansal sıkıntı olarak ifade edilebilecek "financial distress" kavramı çalışmada; finansal baskı ve finansal başarısızlık gibi benzer anlamlara gelebilecek tüm kavramlara karşılık gelmek üzere kullanılmıştır. 
düşebileceğinin tahmini ile sınırlı tutulmamaktadır. Konu esasen daha ciddi ve kötü sonuçların önlenebilmesini teminen böyle bir durumda nasıl bir davranış içerisine girilmesi gerektiği yönünden de büyük önem taşımaktadır (Sarlija \& Jeger, 2011: 133).

Yüksek tahmin gücüne sahip modellerin geliştirilmesi oldukça güç olmakla birlikte finansal sıkıntının tahminine yönelik çalışmalarda da başlangıçta finansal analiz teknikleri kullanılmıştır. Bununla birlikte zaman içerisinde karmaşık iş koşulları nedeniyle matematiksel ve istatistikî tekniklerin kullanımı zorunluluk arz etmiştir. Finansal sıkıntı tahmin modelleri de genellikle; "acze düşme (solvency)2, faaliyet (activity), karlılık, yatırım ve kaldıraç (leverage)" ile ilgili finansal oranlara yönelik finansal bilgiler üzerinden yapılmaktadır. Kendi oranlarının yüksek tahmin gücüne sahip olduğunu belirten çok sayıda çalışma bulunmasına rağmen, tek bir mükemmel finansal oran kombinasyonu henüz bulunabilmiş değildir. Modeller; veri seti, verinin elde edilebilirliği, veri kalitesi ve analiz yöntemine bağlıdır (Sarlija \& Jeger, 2011: 133). Finansal sıkıntı ile ilgili çoğu model iflasla ilgili olduğundan, yalnızca finansal sıkıntıyı ele alan modellerin sayısı ise oldukça azdır (Platt \& Platt, 2008: 132). Bununla birlikte iki kavram arasındaki farklılık, tahmin modellerinin de farklılaşmasını gerekli kılmaktadır. Finansal sıkıntı riskinin nasıl ölçümlenebileceğine yönelik soruların finans literatüründe uzun bir tarihi bulunmakla birlikte sadece kavrama yönelik çalışmaların sayısı oldukça sınırlıdır. Bu durumun temel nedeni ise iflas ve finansal sıkıntı kavramlarının tanımlarından kaynaklanmaktadır. Yasal bir süreci ifade eden iflas kavramı daha net bir şekilde tanımlanabilirken, son aşaması iflas olan finansal sıkıntının tanımı üzerinde bir uzlaşma bulunmamaktadır. Bu durum, ister istemez söz konusu kavramın ölçülmesine yönelik tahmin modellerine de yansımaktadır. $\mathrm{Bu}$ çalışmada kavramların karşılaştırılması, finansal sıkıntı ve iflas modellerinin tahmininde en yaygın bir biçimde kullanılan muhasebe temelli finansal oranlara yönelik teknikler ışığında yapılacaktır. Bu anlamda çalışmanın amacını, iflas ve finansal sıkıntı kavramlarının birbirleri ile ilişkili ancak farklı olduğunun ortaya konularak tahmin modellerinde bu durumunun dikkate alınmasının gerekliliğini açıklamak olarak özetlemek mümkündür. $\mathrm{Bu}$ çerçevede çalışmanın ikinci bölümünde muhasebe temelli tahmin modellerinin gelişimine yer verilecektir. Karşılaştırmanın yapılacağı üçüncü bölümde ise, iflas ve finansal sıkıntı kavramları arasındaki farklılıklar ele alınarak bu durumun tahmin modellerine yansıması ele alınacaktır.

2 Mali başarısızlığa uğrayan işletmeler, genellikle nakit akışını idare etmekte ve kısa vadeli borçlarını ödemekte zorluklarla karşılaşmaktadır. Bu durum işletmenin acze düşmesine neden olmaktadır. Acze düşme, finansal baskı sürecinin aşamalarından biridir ve literatürde; "firmanın dönen ve duran varlıkları toplamının vadesi gelen borçların toplamının altına düşmesi ve borçların vadesi geldiğinde ödenememesi" olarak tanımlanmaktadır (Çakır, 2005: 11). 


\section{Muhasebe Temelli Tahmin Modelleri}

Muhasebe bilgilerinin (finansal oranların), finansal sıkıntıda olan (ve/veya iflas eden) firmalar ile finansal sıkıntı olmayan (ve/veya iflas etmeyen) firmaları birbirlerinden ayırmada kullanılabileceği uzun zamandır finans dünyasının tartı̧malı konularından bir tanesini oluşturmaktadır (Mahdi \& Abedini, 2009: 399). Son on yıllık süreçte ise araştırmacılar ve teorisyenler finansal sıkıntı ve iflasın tahminine yönelik yeni yaklaşımların geliştirilmesine odaklanmışlardır. Finansal sıkıntının tahmini konusunun ekonomik, finansal, muhasebesel, istatiksel hatta bilgi odaklı olarak ele alınması mümkündür. Bu alandaki çalışmaların zamansal olarak 1990 öncesi ve sonrası olarak ikiye ayrılması mümkündür. 1990 öncesi finansal sıkıntı riskini belirlemeye yönelik hakim çalışmalar, finansal sıkıntı yaşayan ve sağlıklı firmaları ayırt edici temel karakteristik özelliği bulmaya odaklanan tek-zamanlı modellerden oluşmaktadır. 1990 sonrasındaki hakim çalışmalar ise her bir firmanın zamanın herhangi bir noktasındaki riskini belirlemeye odaklanmış dinamik çalışmalardır. Finansal sıkıntı tahmin modelleri tarihsel gelişim dışında kullanılan verinin niteliğine göre genellikle; "muhasebe temelli (finansal oranlar)" ve "piyasa temelli" olarak sinıflandırılmaktadır (Outecheva, 2007: 87). Muhasebe temelli modeller firmaların finansal tablolarının kullanılabilirliğini test ederek finansal sıkıntı riskini ölçmeye çalışmaktadır. Bu teknik; "tek bir finansal oran" ya da "çok sayıda finansal oranın" bir oran ya da ağırlıklandırılmış finansal oranlar kombinasyonu ile karşılaştırılarak firmaların finansal sıkıntıda (olan) ya da finansal sıkıntıda olmayan (sağlıklı) firmalar şeklinde ayrıştııılmasını hedeflemektedir. Finansal sıkıntı riskini tahmin etmek için kullanılan muhasebe temelli bu yaklaşımda; "karlılık ve likidite" gibi oranlar ardıl (ex-post) olarak ölçümlenmektedir. Finansal bilgilerin basitliği ve elde edilebilirliği bu tekniğin son on yılllık süreçte ampirik araştırmalar bakımından en yaygın biçimde kullanılmasına neden olmuştur (Outecheva, 2007: 88).

Finansal oranlar, finansal başarısızlık eğilimini ortaya koymaya çalışan modellerde sağladığı bir takım üstünlükler nedeniyle genelde bağımsız değiş̧ken olarak kullanılmaktadır. Sadece bir oranın bağımsız değişken olarak kullanıldığı tek boyutlu modeller, çok boyutlu modellere kıyasla uygulama kolaylı̆̆g açısından daha üstün olmakla beraber, çelişkili sonuçlara yol açması, öngörü gücünün düşük olması gibi açılardan eleştirilmektedir. Tek boyutlu modellerin bu sakıncalarından dolayı finansal başarısızlık riskini ölçmede genellikle çok boyutlu modeller kullanılmaktadır. Çok boyutlu modellerin ise belirli bir teoriye dayanmaması eleştirilmekle beraber, bu modellerin genelde sağladığı

3 Yapılan bir diğer sınıflandırmada finansal başarısızlığın tahminine yönelik erken uyarı modelleri; "şirket kazançlarının (karlarının) tahminine yönelik modeller", "şirket iflaslarının tahminine yönelik oran bazlı modeller" ve "şirket iflaslarının tahminine yönelik ekonomik trend bazlı modeller" olmak üzere üç ana grup altında toplanmaktadır (Atan \& Çatalbaş, 2004: 3). 
başarı konunun uzmanlarınca ilgi çekici bulunmaktadır. Çok boyutlu modellerin gösterdiği istikrar yapılan savunmaların odağını oluşturmaktadır. Çok boyutlu modellerde farklı istatistiksel yöntemler kullanılmaktadır. Bu yöntemlerden yazında en sık rastlananlar; çoklu regresyon modeli, diskriminant analizi ve logit modelleridir (Aktaş vd., 2004: 4-5). Şirket iflaslarının tahminine yönelik finansal oran bazlı (muhasebe temelli) modellere yönelik çok sayıda çalışma bulunmaktadır. Ancak bu konudaki literatürün Beaver (1966) ve Altman (1968)'ın çalışmaları ile başladığını söylemek yanlış olmayacaktır (Atan \& Güneş, 2004: 3).

Modern finansal sıkıntı riski değerlemesinin öncülerinden biri olan Beaver (1966), kurumsal başarısızlığın tahmini için tek değişkenli istatiksel teknikler uygulamıştır. Beaver, çalışmasında kullandığı ve finansal başarısızlığa uğrayan 79 firmanın temerrüt öncesine ait 5 yılı kapsayan 30 adet finansal oranının belirlenmesinde; "literatürde görülme sıklığı/popülarite, performans oranları ve nakit-akış teorisine ait olma" şeklindeki kriterleri dikkate almıştır. Beaver, risk kavramını tanımlamamakla birlikte, nakitin (rezervoir) tükenmesinin temerrüt riskini artırdığını belirtmiştir. Beaver'ın çalışmasına dayanak oluşturan ve teorik bir temelden daha ziyade mantıksal bir zemine oturan "nakit akış yaklaşımı"; "likit varlıklar ve faaliyetlerden kaynaklanan nakit girişleri ne kadar artarsa temerrüt riski o ölçüde azalır" ve "toplam borçlar ve faaliyetlerden kaynaklanan nakit çıkışları ne kadar artarsa temerüt riski o kadar artar" şeklinde dört önermeye dayanmaktadır. Beaver'ın çalışmasında, finansal sıkıntıdaki firmanın tespitinde \%22 ve sağlıklı firmanın tespitinde ise \% $\%$ 'lik bir hata gözlemlenmiştir. Bununla birlikte temerrüt tarihinden uzaklaşıldıkça finansal sıkıntılı firmanın tespitindeki hataların arttığı görülmüştür (Outecheva, 2007: 89).

Beaver'ın işletmelerin iflas etme riskini, firmaların vadesi gelen borçların ödeme kapasitesi bulunmayışıyla açıklamaya çalıştığını söylemek mümkündür. Beaver, özellikle finansal başarısızlığa uğramış firmaların finansal oranlarının, başarılı firmaların oranlarından farklı olduğunu ve bu farklılığın 5 yıl öncesinden başladığını saptamıştır (Atan \& Güneş, 2004: 3). Beaver, çalışmasında, aşağıda yer verilen beş oranın iflasların öngörülmesinde önemli bir gösterge olduğu sonucuna ulaşmıştır. Beaver'e göre; "net nakit akış1/toplam yabancı kaynaklar" oranı iflasları açıklamak bakımından en önemli göstergedir (Sayılgan, 2008: 408).

Beaver'ın tahminleri kısa dönemler bakımından iyi sonuçlar ortaya koymakla birlikte çalışma ile ilgili çeşitli eleştiriler bulunmaktadır. Öncelikli olarak tek bir finansal oran hesaplanması zamansal olarak finansal oranların değişimini göstermemektedir. İkinci olarak tek bir finansal oran aynı firma için dahi farklı oran sınıflandırması bakımından tutarlı olmayan sonuçlar üretmektedir. Üçüncü sorun ise muhasebe verilerinin kendi aralarındaki yüksek korelasyondan kaynaklanmaktadır. Son olarak örnek alınan firmaların 
başarızlık olasılı̆̆ının tüm evren için aynı olmadığının söylenmesi mümkündür. Beaver'ın çalışması sonrasında, Altman (1968) tarafından, Beaver'ın çalışmasının zayıf yönlerinin elimine edilmesine yönelik olarak; "Hangi oranlar potansiyel iflasın belirlenmesinde en önemlidir?, Söz konusu oranların ağırlığı nedir? Söz konusu ağırlıklar nasıl objektif bir biçimde belirlenebilir?" sorularının ele alındığı yeni bir çalışma ortaya konulmuştur (Outecheva, 2007: 90).

Tablo: 1

Beaver ve Altman'ın Çalışmalarında Kullanılan Finansal Oranlar (Değişkenler)

\begin{tabular}{|l|l|c|l|}
\hline \multicolumn{1}{|c|}{ Beaver (1966) } & & \multicolumn{1}{|c|}{ Altman (1968) } \\
\hline 1 & Net Nakış Akış//Toplam Yab. Kaynaklar & $X_{1}$ & Net İşletme Sermayesi/Toplam Aktifler \\
\hline 2 & Net Kâr / Özkaynaklar & $X_{2}$ & Dağıtılmamış Kâr/Toplam Aktifler \\
\hline 3 & Dönen Varlıklar / KV Yabancı Kaynaklar & $X_{3}$ & Faiz ve Vergi Öncesi Kâr/Toplam Aktifler \\
\hline 4 & Borç / Özkaynaklar & $X_{4}$ & Hisse Senetlerinin Piyasa Değeri /Borçların Defter Değeri \\
\hline 5 & İşletme Sermayesi / Özkaynaklar & $X_{5}$ & Net Satışlar/Toplam Aktifler \\
\hline
\end{tabular}

Altman yaptığı çalışma ile işletmelerin iflaslarının tahmininde ilk defa çok değişkenli analiz yöntemlerini kullanmış ve finansal oranların ağırlıklarını ve karşılıklı ilişkilerini dikkate alarak iki firma grubunu birbirinden en iyi ayıran bir diskriminant fonksiyonu elde etmeye çalışmıştır (Atan \& Güneş, 2004: 3). Altman tek değişkenli oran analizini analitik bir tekniğe dönüştürmüştür. Altman çok değişkenli diskriminant analizi kullanarak, finansal sıkıntılı ve sağlıklı firmaları finansal olarak ayıran en iyi lineer oran kombinasyonunu elde etmeye çalışmıştır. Çalışmada, 1946 ve 1965 yılları arasında iflas eden 33 firma, aynı endüstride ve aynı büyüklükteki 33 sağlıklı firma ile karşılaştırılmıştır. Çalışmada yer alan tüm firmaların varlık değeri 1 milyon ABD Doları üzerindedir. Firmalar imalat sanayinden seçilmişlerdir. Altman, Beaver'e benzer şekilde, popülerlik derecesini de dikkate aldığı 22 finansal oranı; "karlılık, likidite, borçlanma (leverage), ödeme gücü (solvency) ve faaliyet" başlıkları altında sınıflandırmıştır (Outecheva, 2007: 90).

Altman'ın diskriminant analizi kullanarak geliştirdiği ve Altman-Z skoru (ve/veya değeri) olarak adlandırılan iflas tahmin modelinde Tablo: 1'de yer verilen; "işletme sermayesi/toplam varlıklar, dağıtılmayan karlar/ toplam varlıklar, EBIT/toplam varlıklar, hisse değeri/toplam yükümlülükler ve satışlar/toplam varlıklar" olmak üzere 5 adet oran kullanılmıştır (Janes, 2003: 5). Altman'ın, finansal oranları belli katsayılar ile çarparak geliştirdiği modelin formülasyonu aşağıdaki gibidir (Altman, 2000: 9):

$$
\mathrm{Z}=1,2 \mathrm{X}_{1}+1,4 \mathrm{X}_{2}+3,3 \mathrm{X}_{3}+0,6 \mathrm{X}_{4}+1, \mathrm{X}_{5}
$$


Finansal risk belirlenmesinde kullanılan birleşik rasyonun yorumu şu şekildedir (Poyraz \& Didin, 2008: 6):

- $\quad$ Z Değeri < 1.81 ise; işletme ciddi boyutta finansal başarısızlık riski taşımaktadır,

- $\quad 1.81<\mathrm{Z}$ değeri < 2.99 ise; işletmenin geleceği çok parlak değil ama finansal başarısızlık riski düşük olduğu şeklinde yorumlanmakta,

- $\quad Z$ değeri > 3 ise; işletme hiçbir finansal güçlüğün bulunmadığının ve finansal başarısızlık olasılığının olmadığının bir göstergesi olarak yorumlanmaktadir.

Altman'ın modeli Beaver'ın tek değişkenli tekniğine nazaran daha doğru sonuçlara ulaşmıştır. Model finansal sıkıntıdaki firmaları \%6 ve sağlıklı firmaları \%3 hata payılla saptamaktadır (Outecheva, 2007: 91). Test çalışmalarına göre, model toplamda iflastan 5 yıl önce \%70 oranında, iflastan bir önceki yıl \%96 oranında iflası öngörebiliyor sonucuna ulaşmıştır (Sayılgan, 2008: 408). Bununla birlikte süreç içerisinde gelen çeşitli eleştiriler doğrultusunda Altman modelinde bazı değişikliklere gitmiştir (Outecheva, 2007: 91). Altman, hisse senetlerinin piyasa değerinin halka açık olmayan şirketlerde nasıl belirleneceği eleştiriler sonrası modelde

$\mathrm{X}_{4}=$ Öz Sermayenin Cari Değeri/Borçların Defter Değeri

oranına yer vermiştir. Bu durumda model aşağıdaki şekilde değişikliğe uğramıştır (Altman, 2000: 25-26):

$$
\mathrm{Z}=0,717 \mathrm{X}_{1}+0,847 \mathrm{X}_{2}+3,107 \mathrm{X}_{3}+0,420 \mathrm{X}_{4}+0,998 \mathrm{X}_{5}
$$

Yeni modelde $\mathrm{Z}$ değeri ise; $1,23<\mathrm{Z}<2,99$ olarak belirlenmiştir.

Altman Z-skoru, finansal sıkıntı riskinin tahminine yönelik muhasebe temelli teknikleri önemli ölçüde iyileştirmiştir. Z-skoru finansal sıkıntılı ve sağlıklı firmaları en iyi ayıran ağırlıklandırılmış finansal oranları temsil etmektedir. Yapılan çok sayıda çalışma, temerrüde bir yıl kala olan dönem bakımından Altman'ın Z-skorunun, Beaver'ın tek değişkenli modeline göre çok yüksek doğruluğa sahip olduğunu ortaya koymuştur. Bununla birlikte Z-skorunun, endüstriden endüstriye ilgili oranların değişmesi, tekniğin örneklem büyüklüğüne ve açıklayıcı değişken sayısına duyarlı olması ve modelin çok sayıda kısıtlayıcı varsayıma dayanması gibi çeşitli sınırları bulunmaktadır. Ohlson (1980), Z-skorunun eksikliklerini azaltmak için alternatif bir teknik olaral logit modeli kurgulamıştır. Diskriminant analizine benzer şekilde modelde bağımsız değişkenler 
ağırlıklandırılarak bir değere ulaşılmaktadır. Bununla birlikte diskriminant analizinden farklı olarak modelde örneklem içinde yer alan firmanın temerrüt olasılığı tahmin edilmeye çalışılmaktadır (Qutecheva, 2007: 92). Ohlson'un, finansal raporların tarih bilgileride dahil olmak üzere iyileştirdiği veri seti, firmaların söz konusu tarih öncesinde veya sonrasında temerrüde düşüp düşmediğinin karşılaştırılabilmesine olanak sağlamıştır. Çalışmanın final aşaması 1970 ve 1976 yılları arasında iflas eden 105 endüstriyel firma ile 2058 iflas etmemiş firmayı kapsamaktadır. Ohlson temerrüd tahmin edicileri olarak bir yıl içinde gerçekleşecek temerrüt olasılığını ortaya koyan dört faktörü; "firma büyüklüğü, finansal yap1 ölçümü, performans ölçümü ve cari likidite ölçümü” olarak belirlemiştir. O-skor olarak da bilenen formül aşağıdaki gibidir (Outecheva, 2007: 93):

O-Skor $=-1.32-0.407 \log$ (toplam varlıklar / GNP fiyat endeksi) +6.03 (toplam yükümlülükler/toplam varlıklar) - 1.43 (işletme sermayesi / toplam varlıklar ) + 0.076 (cari yükümlülükler / toplam varlıklar) - 1.72 (eğer toplam yükümlülükler toplam varlıklardan büyükse 1 değilse 0 ) - 2.37 (net gelir /toplam varlıklar) - 1.83 (faaliyetlerden fonlar / toplam yükümlülükler) +0.285 (eğer son iki yılda net zarar mevcutsa 1 değilse 0$)-0.521$ [(net gelir ${ }_{t}-$ net gelir $\left._{\mathrm{t}-1}\right) /\left(\right.$ net gelir $_{\mathrm{t}}+$ net gelir $\left.\left._{\mathrm{t}+1}\right)\right]$

O-skorun büyüklüğü aynı zamanda temerrüt riskinin de artması anlamına gelmektedir. Ohlson çalışmasında, önceki çalışmalara nazaran, finansal sıkıntılı ve sağlıklı firmaların tespitindeki hataların 0,038 minimize edildiğini ortaya koymuştur. Sınırlı bir iyileşmenin sağlandığı çalışmadaki en önemli tahmin edici olarak firma büyüklüğü öne çıkmaktadır (Outecheva, 2007: 94).

Ohlson'un (1980) modelinde kullandığı; “toplam yükümlülükler/toplam varlıklar, net gelir/toplam varlıklar, işletme sermayesi/toplam varlıklar" oranlarının yanı sıra, Zmijewski'nin (1984) modelinde; "net gelir/toplam varlıklar, toplam yükümlülükler/toplam varlıklar, dönen varlıklar/kısa dönem yükümlülükler"; Shumway'in (2001) modelinde ise; "net gelir/toplam varlıklar, toplam yükümlülükler/toplam varlıklar" ve çeşitli menkul kıymet verileri kullanılmıştır. Modellerdeki ortak noktalardan bir tanesi kazancın ölçülmesidir. Her bir modelde yüksek kazanç düşük iflas riski ile ilişkilendirilmektedir (Janes, 2003: 5).

1980'li y1llarda şirket iflaslarının tahminine yönelik ekonomik trend bazlı modeller incelendiğinde ise en ilginç olanı, Rose'un yaptığı araştırma olarak karşımıza çıkmaktadır. Araştırmacılar, 10 yıllık bir süreyi kapsayan bu araştırmada şirketlerin başarısızlığa uğramalarını "a) Borsa endeksi b) Özel yatırımlar / GSMH c) Net kar / şirketin yarattığı katma değer d) Faiz Oranları e) Perakende satışlar / GSMH” şeklindeki 5 değişkene bağlamışlardır (Atan \& Çatalbaş, 2004: 5). Esasen, Ohlson'da çalışmasında, Rose'un çalışmasına benzer şekilde, "hisse fiyatı" veya "hisse fiyatının dalgalanması" gibi muhasebe temelli olmayan verilerin de ileriki araştırmalarda dikkate alınmasını 
önermektedir. Muhasebe temelli olmayan verilerin kullanımı piyasa tarafindan belirlenen firma değerine dayalı risk modellerinin gelişimine olanak sağlamıştır. Bu çerçevede halen en geniş kullanım alanına sahip muhasebe temelli yaklaşımların noksanlıklarının piyasa temelli modeller ile tamamlanabilmesi mümkündür (Outecheva, 2007: 94).

Yeni metodolojilerin uygulanması ile bu alana yönelik çalışmalar devam etmiştir. Uygulanan modeller arasında çeşitli farklılıklar bulunmakla birlikte, iflas tahminlerine yönelik faktörler olarak; "borç, karlılık, likit olma, faaliyet performansı ve büyüme" öne çıkmaktadır. Başlatan olaydan bağımsız olarak, iflas eden firmalar, yaşayabilir olabilmek için, faaliyetlerin yeniden yapılandırılmasında mahkemeler ile birlikte çalışmaktadır. Bununla birlikte, finansal sıkıntıdaki firmalar yasal müracaatı gerektirecek yetersizliğe henüz ulaşmamış durumdadır. Bu nedenle finansal sıkıntı yaşayan firmalar sıklıkla; "varlık satışı, yönetim değişimi, çalışma sermayesi iyileştirmesi" gibi tedbirlere yönelmektedirler (Platt \& Platt, 2008: 131). Bu anlamda tahmin modellerinin doğruluğunun yalnızca seçilen tekniğe değil aynı zamanda verilerin elde edilebilirliği ve yapısı yanında, sınıflandırmaya yönelik yapılan varsayımlara bağlı olduğunu söylemek mümkündür (Outecheva, 2007: 94).

\section{3. İflas ve Finansal Sıkıntı Farklıı̆̆ının Tahmin Modellerine Yansıması}

Altman'ın (1968) çalışmasında da yer alan kurumsal iflasın temel belirleyici kodları; bankalar, yatırımcılar, kredi yöneticileri, düzenleyiciler arasında, finansal riskin azaltılmasına olanak sağlamıştır. Bununla birlikte, iflas tahminleri, finansal sıkıntıdaki firmaların yöneticilerine çok az zaman sağlamaktadır. Çoğu durumda iflas, finansal sıkıntı sürecini müteakip meydana gelmektedir. Sağlıklı firmaların finansal sıkıntı yaşayabileceğine dönük öngörüler ise iflasın ya da düşüşün önüne geçilmesine yardımcı olabilecektir. Finansal sıkıntı ve iflas arasındaki farkın anlaşlabilmesi hangi finansal sıkıntı durumlarının iflasa dönüşebileceğinin tespitine de yardımcı olacaktır. Bu noktada doğal olarak ortaya atılan soru, olası iflasın göstergeleri olan faktörlerin acaba olası finansal sıkıntı içinde geçerli olup olmadığına yöneliktir. Kavramsal olarak soru, acaba finansal olarak sıkıntıda olup iflasa giden firmaların standart bir yolu takip edip etmedikleri veya çeşitli davranışlar ile belirlenen farklı çözüm arayışlarının onları iflasa götürüp götürmediğinde düğ̈̈mlenmektedir. $\mathrm{Bu}$ durumda iflası tahmin etmeye yarayan modellerin finansal sıkıntıları tahmin edip edemeyeceklerinin ortaya konulması gerekmektedir (Platt \& Platt, 2006: 141-142). 
İflas ve tasfiye ${ }^{4}$ kavramlarının tanımı finansal sıkıntıya göre daha belirli olmakla birlikte, finansal sıkıntı olasıllğının ölçülebilmesi için kavramın tanımlanması büyük önem taşımaktadır (Platt \& Platt 2006: 142). Finansal sıkıntı kavramının iflas ile eşit koşullar altında değerlendirilmesi durumunda çok az sayıda firmanın bu konumda olduğu kabul edilebilir. Kavramın daha geniş bir biçimde çeşitli yükümlülüklerin yerine getirilememesi şeklinde ele alınması durumunda ise çok sayıda firmanın sıkıntı yaşadığ görülecektir (Damodaran, 2009: 27). Finansal sıkıntı kavramının herkesin üzerinde uzlaştı̆̆ 1 genel kabul gören bir tanımı bulunmamaktadır. İflas başvurusunda bulunan bir firmanın genel olarak finansal sıkıntı yaşadığı kabul edilmekle birlikte, bu durum finansal sıkıntı sürecinin en uç noktasını oluşturmaktadır. İflas başvurusunda bulunan firmanın finansal sıkıntıları başvuru öncesine uzanmakla birlikte sürecin ne zaman başladığını belirlemek oldukça güçtür (Janes, 2003: 10). Finansal sıkıntı tanımının, sürecin ilk gelişim periyodunu da kapsaması gerekmektedir. Bununla birlikte finansal sıkıntı yaşanmaya başlamış ve her ne kadar dolaylı maliyetlerin çoğunun etkisi görülmüş olmakla birlikte, firma için reaksiyon ve geri dönüşüm mümkündür (Pindado \& Rodriguez, 2005: 345).

Görüldüğü üzere, iflas ve finansal sıkıntı basitçe aynı sürecin birbirini takip eden iki adımı değildir. Finansal sıkıntı yaşayan firmalar kötü faaliyet sonuçlarına sahipken, iflas, firmaların varlıklarını korumak için aldıkları bir durumu yansıtmaktadır. Finansal sıkıntının iflaslardan daha az çalışılması büyük ölçüde, iflasın hukuki bir zeminde tanımsal bir başlangıç tarihine sahip olmasına rağmen, finansal sıkıntının özel bir tanımdan yoksun olmasından kaynaklanmaktadır. Finansal sıkıntının ne zaman başladığı ve sona erdiği net değildir. Ayrıca finansal sıkıntı dereceleri de firmalara göre değişmektedir. Araştırmacılar kavrama yönelik çok çeşitli tanımlar geliştirmiştir (Platt \& Platt, 2008: 132).

Literatürde yer alan ve çok sayıda ampirik çalışmada kullanılan söz konusu farklı tanımların; finansal sıkıntı kavramınının "olay bazlı (event-oriented)", "süreç-bazlı (process-oriented)" ve "tekniksel (technical)" olarak ele alınması sonucu üç ana kategoride sınıflandırılmasına neden olduğu görülmektedir. İlk sinıflandırma olan olay bazlı tanımlamada finansal sıkıntının genellikle; "iflas, temerrüt ve başarısızlık" durumlarına karşılık gelmek üzere kullanıldığı görülmektedir. Bu tanımlamada örneğin borçların ödenmesinde temerrüde düşülmesi şeklindeki tek bir olay finansal sıkıntı olarak

4 Birbirleri ile ilgili olan tasfiye ve iflas kavramları da literatürde sıklıkla tartışılmaktadır. Tasfiye firma varlıklarının parça parça veya bir bütün olarak başka bir firmaya satılmasını ifade etmektedir. Tasfiye kararı, firma varlıklarının alternatif kullanımlarının daha yüksek olduğu zamanlarda optimal olmaktadır. Tasfiye, firmanın nasıl finanse edildiğinden bağımsız olarak, bir sermaye bütçelemesi (yatırım) kararı olarak görülmelidir. Tasfiye ve iflas ayrı ve bağımsız olaylardır. Karlı fakat yüksek borçlanma oranına sahip firma faaliyetlerine devam edebilirken, borcu olmayan ancak kar etmeyen bir firmanın tasfiye edilmesi mümkündür (Senbet \& Wang, 2012: 8). 
nitelendirilmektedir. Süreç bazlı tanımlama ise, firmanın sağlıklı hali ve iflas arasındaki süreçteki yaşananları dikkate alan karmaşık olayların anlaşılmasına yönelik katkıda bulunmuştur. $\mathrm{Bu}$ tanımlamayı kullananlar finansal sıkıntıyı temerrüt ya da iflastan tamamen farklı görmüşler ve firmanın sağlıklı hali ve aczi arasındaki süreci bütünsel olarak değerlendirmeye almışlardır. Bu durumda finansal sıkıntı çeşitli elverişsiz finansal olayların birbirini takip ettiği süreçlerin bir bütününü ifade etmektedir. Son sınıflandırmaya ait tanımlama ise finansal sıkıntının temel değişkenlerinin açıklanmasına yöneliktir. Söz konusu değişkenler genellikle ampirik çalışmalarda finansal sıkıntının tahminine yönelik kullanılmaktadır. Finansal sıkıntıya yönelik yapılan çalışmalarda kullanılan en önemli değişkenler olarak firmanın finansal oranlarını söylemek mümkündür. Oldukça popüler olan muhasebe temelli söz konusu değişkenler yaygın bir şekilde kullanılmaktadır. Görüldüğü üzere, finansal sıkıntıya yönelik çeşitli yaklaşımlar konunun çok taraflı, karmaşık ve zorlu olduğunu ortaya koymaktadır. Bu anlamda kavramın tanımının; duruma göre finansal, operasyonel veya hukuki bakış açısı ile yapılan ampirik çalışmanın amacına göre şekillendiğini söylemek mümkündür. Bununla birlikte finansal sıkıntı kavramına yönelik tanımların benzer ekonomik kriterler 1şı̆̆ında formal tutarlılığı yansıtacak şekilde konsolide edilmesine ihtiyaç bulunmaktadır. Modern yaklaşımlar kavramın; "çeşitli ekonomik sinyalleri uyandıran değişik karakterli" heterojen ve dinamik bir süreç olduğunu ifade etmektedir (Outecheva, 2007: 14-19).

Finansal sıkıntının tespiti bakımından iflas teorisi ve diğer deneysel çalışmalarda; "borç (leverage), karlılık (profitability), likit olma (liquiditiy), nakit akımı (cash flow) ve firma büyüklüğü (size)" kavramları öne çıkmaktadır. Buna ek olarak finansal oranları gösterge olarak kullanan çalışmalar, olay öncesi son 5 yıla ait veriler ile iflasın tahminini büyük bir doğrulukla yapılabileceğini ortaya koymaktadır. Bununla birlikte finansal sıkıntı yaşayan firmalar arasında ilk işaretlerin ve işaretlerin zamanlamasının farklı olması nedeniyle, iflas eden firmalar (failing firms) farklı finansal sıkıntı süreçlerine sahiptir. Bir başka deyişle, iflas eden firmalara ait finansal oranlar her durumda aynı sonuçları yansıtmamaktadır. Bu nedenle, özel süreçlerin tanımlanabilmesi finansal sıkıntı tahmininin daha iyi anlaşılmasına yardımcı olacaktır. Bu anlamda finansal sıkıntı sürecinde, finansal göstergeler süreç içerisindeki önemlerini devam ettirirken, finansal sıkıntı işaretlerinin daha görünür olması ile göstergelerin göreceli önemi azalacaktır. $\mathrm{Bu}$ nedenle finansal sıkıntı sürecinin farklı aşamalarının tanımlanması gerekmektedir. Söz konusu aşamalar özetle üçe ayrılmaktadır. Erken aşamada; "finansal tablolar karlılıkta azalmayı", geç aşamada; "finansal tablolar karlılıkta azalmayı ve borçlanmadaki artışı" ve final aşamasında ise "finansal tablolar karlılıkta azalmayı, borçlanmadaki artışı ve likiditedeki azalmayı" göstermektedir (Sormunen \& Laitinen, 2012: 45-46). Finansal sıkıntı süreci aşamaları, finansal oranların sınıflandırma kabiliyetini etkilemektedir. Buna göre likit rasyolar (cari oran, faaliyet nakit akışı oranı, net işletme sermayesi oranı) final aşamasından uzaklaştıkça tahmin yeteneklerini kaybetmektedir. 
Benzer şekilde karlılık oranları da zaman aralığının artmış olduğu durumlarda tahmin yeteneğini kaybetmektedir. Bununla birlikte, finansal sıkıntının final aşamasında ve firmanın yeniden organizasyonuna ilişkin durumlarda, firmanın likiditesini ölçmeye yarayan finansal oranlar en önemli tahmin göstergeleri olarak öne çıkmaktadır (Sormunen \& Laitinen, 2012: 64).

Platt ve Platt (2006) kurguladıkları modelde çeşitli değişkenlere yer vermiştir. Bu değişkenlerden yalnızca "nakit akışı / net satışlar" oranı, hem finansal sıkıntı hem de iflas ile ilgili modelde de yer almıştır. Modellere göre, "nakit akışı / net satışlar" değişkeni hem finansal sıkıntı hem de iflas ile ters orantılıdır. Her ne kadar iflas modelinde yer alan "kısa dönem borç / toplam borç" değişkeni, finansal sıkıntı modelindeki "uzun dönem borçların cari kısmı / toplam varlıklar" oranıyla benzeşmesine rağmen farklıdır. Modellerdeki değişkenler ve değişkenlerin finansal sıkıntı ve iflas ile ilişkileri aşağıdaki gibidir (Platt \& Platt, 2006: 152):

Tablo: 2

İflas ve Finansal Sıkıntı Modellerinin Karşılaştırııması

\begin{tabular}{|l|c|l|c|}
\hline \multicolumn{1}{|c|}{ İflas Modeli } & \multicolumn{2}{c|}{ Finansal Sıkıntı Modeli } \\
\hline \multicolumn{1}{|c|}{ Değişkenler } & İlişki & \multicolumn{1}{c|}{ Değişkenler } & İlişki \\
\hline Nakit Akışı / Satışlar & - & Nakit Akışı / Satışlar & - \\
\hline Toplam Borç / Toplam Varlıklar & + & & \\
\hline Net Sabit Varlıklar / Toplam Varlıklar & + & & \\
\hline KV Borçlar / Toplam Borç & + & & \\
\hline $\begin{array}{l}\text { Nakit Akış1 / Satışlar*Endüstri Toplam } \\
\text { Üretim Değişikliği }\end{array}$ & - & & \\
\hline $\begin{array}{l}\text { Toplam Borç / Toplam Varlıklar* } \\
\text { Endüstri Toplam Üretim Değişikliği }\end{array}$ & + & & \\
\hline $\begin{array}{l}\text { Satışlardaki Büyüme / Endüstri Toplam } \\
\text { Üretim Değişikliği }\end{array}$ & - & & \\
\hline & & EBITDA/Toplam Varlıklar & - \\
\hline & & Cari UV Borç /Toplam Varlıklar & + \\
\hline & & Faiz Kazanç Periyodu & - \\
\hline & & Likidite (Asit-Test) Oranı & + \\
\hline
\end{tabular}

Kaynak: Plat \& Plat, 2006: 152. 
Tablo: 2'den görüldüğü üzere, çalışmada finansal sıkıntı $\mathrm{EBITDA}^{5}$ ve faiz kazancı gibi gelir tablosu temelli değişkenler ile ölçülmüştür. Her iki modelde ortak olan; "nakit akışı/satışlar" oranı dışında, iflasa yönelik modellerde gelir tablosu temelli değişsken bulunmamaktadır. Gelirde meydana gelen sapmalar doğrudan bir kararı gerektirmeksizin firmanın farklı yollarla çözebileceği bir durumdur. Bununla birlikte iflas tahmin modelleri; "toplam borç, kısa dönem borç ve net sabit varlık" olmak üzere bilanço temelli üç anahtar rasyoya dayanmaktadır. Finansal sıkıntıda yer alan tek borç rasyosu ise uzun dönem borçların cari kısmına yöneliktir. Bilanço değişkenleri finansal sıkıntı ve iflas arasındaki farkı çok açık bir biçimde ortaya koymaktadır: İflas, borç yükü ile ilgili iken, finansal sıkıntı, firmanın ihlal ettiği borç sözleşmelerinin neden olduğu uzun dönem borçların, cari dönem borç haline gelmesinden etkilenmektedir. Borç sözleşmelerinin ihlali firmanın planlarının aksamasına neden olmaktadır. Ağır borç yükü, finansal sıkıntıyı takip eden kurumsal bir karar sürecidir. $\mathrm{Bu}$ anlamda iflas, firmanın varlıklarını alacaklılardan korumaya çalışması sonrasında almaya ihtiyaç duymuş olduğu bir karardır. Finansal sıkıntı firmanın faaliyet sonuçlarının memnun edici olmamasından kaynaklanmaktadır. $\mathrm{Bu}$ anlamda finansal sıkıntı yalnızca kötü finansal tercihlerden değil özellikle firmanın faaliyet planlarının uygulanmasındaki başarısızlıklardan kaynaklanmaktadır. Platt ve Platt (2006) tarafından yapılan çalışmada, finansal sıkıntı ve iflasların aynı süreçler olmadığı ortaya konulmuştur. Finansal sıkıntı firmaların faaliyet performanslarının beklentinin altına düşmesi halinde yaşanırken, iflas ise, aşırı borç benzeri problemlerin ortadan kaldırılmasına yönelik bir karardır (Platt \& Platt, 2006: 154- 155).

\section{Sonuç}

Yaşanan finansal krizler, finansal sıkıntı ve iflaslara yönelik tahmin modellerinin önemini bir kez daha ortaya koymuştur. Tek bir firmanın dahi sıkıntıya girmesi, hissedarlar, kreditörler, girişimciler, yatırımcılar gibi çok çeşitli paydaşlar üzerinde ciddi bir etkiye sahipken bu durumun sektörel ya da ekonomi genelinde yaşanması ise önemli toplumsal sonuçlara yol açmaktadır. Esasen finansal sıkıntıya yönelik çalışmaların son elli yıldır varlığından bahsedilmesi olanaklıdır. İlk modeller tek bir finansal oranının açıklama gücünü ölçmeye odaklanmışken günümüzde ise kavramın karmaşıklığı ölçüsünde yeni modeller geliştirilmektedir. Bununla birlikte finansal sıkıntı kavramının net ve üzerinde herkesçe uzlaşılan bir tanımı olmaması nedeniyle, yapılan modeller genellikle iflasların tahmini ile ilişkilendirilmiştir.

Finansal sıkıntı, ilişkili olmakla birlikte, belirli ölçülerde iflastan ayrılmaktadır. İflas kavramı sürecin son aşamasını ifade ederken çoğunlukla firmaların sözleşmelere ait

\footnotetext{
5 Earnings before interest, tax, depreciation and amortization (faiz, amortisman (itfa) ve vergi öncesi kar).
} 
yükümlüklerinin yerine getirilmemesi ile ilgilidir. Bu anlamda iflas finansal açıdan daha çok firmanın bilançosu ile ilişkilendirilmektedir. $\mathrm{Bu}$ durum bizi borç kavramına yönlendirmektedir. Bununla birlikte finansal sıkıntının başlangıcı daha çok firmanın faaliyetleri ile ilgi olup finansal açıdan gelir tablosu ile ilişkilendirilmektedir. Bu durum ise bizi likidite kavramına yönlendirmektedir. Vadesi gelen borçların ödenmesi likidite ile ilgili iken, likiditenin de borçlanma ile yakın bir ilişkisi bulunmaktadır.

Kısaca özetlenmeye çalışılan bu durum, birbirleri ile çok yakından ilgili finansal sıkıntı ve iflasın belirli ölçüde farklılaştığı ve dolayısıyla tespitine yönelik çalışmalarda da daha farklı yaklaşımların benimsenmesi gereğini ortaya koymaktadır. İflasın, finansal sıkıntının son aşamasını ifade ettiği düşünüldüğünde, iflas tahmin sonuçlarının yöneticilere finansal sıkıntının önlenmesine yönelik yeterli süreyi sağlayamaması riski bulunmaktadır. Kavramın tam olarak ortaya konulmasını temin eden tek bir mükemmel modelden bahsedilmesi olanaklı olmamakla birlikte, mevcut az sayıdaki çalışmanın önümüzdeki dönemlerde farklı açılardan çoğaltılmasının gerekli olduğu düşünülmektedir.

\section{Kaynakça}

Aktaş, R. \& M. Doğanay \& B. Yıldız (2004), "Mali Başarısızlı̆̆ın Öngörülmesi; İstatiksel Yöntemler ve Yapay Sinir Ağı Karşılaş̧ırması", Ankara Üniversitesi SBF Dergisi, 58-4, <http://www.politics.ankara.edu.tr/dergi/pdf/58/4/1_ramazan_aktas_mete_doganay_birol _yildiz.pdf>, 16.07.2014.

Atlaş, D. \& S. Giray (2005), "Mali Başarısızlı̆ın Çok Değiş̧kenli İstatiksel Yöntemlerle Belirlenmesi: Tekstil Sektörü Örneği”, Sosyal Bilimler Dergisi, 2005/2, $<$ http://ww.w.asosindex.com/journal-article-abstract?id=865\#.UhZU0xtSjv0〉, 16.07.2014.

Altman, Edward I. (2000), Predicting Financial Distress of Companies: Revisiting The Z-Score and Zeta Models, <www.stern.nyu.edu/ ealtman/Zscores.pdf>, 16.07.2014.

Atan, M. \& B. Güneş (2004), “iMKB’ye Kote Şirketlerde Bilançoya Dayalı Risk Analizi ve Erken Uyarı Göstergelerinin Araştırılması”, 4. İstatistik Günleri Sempozyumu, Dokuz Eylül Üniversitesi, İzmir-Kuşadas1, 19-22 Mayıs 2004.

Atan, M. \& E. Çatalbaş (2004), "Çok Değişkenli İstatistiksel Analiz Yöntemleri İle Türk Bankacılık Sektöründe Çok Boyutlu Mali Başarısızlık Tahmin Modelleri Oluşturulması", 4. İstatistik Günleri Sempozyumu, Dokuz Eylül Üniversitesi, İzmir-Kuşadas1, 19-22 Mayıs 2004.

Buehler, Kevin \& Hamid Samandari \& Christopher Mazingo (2009), "Capital Ratios and Financial Distress: Lessons From The Crisis", Risk Practice, McKinsey Working Papers On Risk, McKinsey\&Company. 
Çakır, Murat (2005), "Firma Başarısızlığının Dinamiklerinin Belirlenmesinde Makine Öğrenme Teknikleri: Ampirik Uygulamalar ve Karşılaştırmalı Analiz”, Uzmanlık/Yeterlik Tezi, Türkiye Cumhuriyet Merkez Bankası, Ankara.

Damodaran, A. (2009), Valuing Distressed and Declining Companies, Stern School of Business, June, <http://people.stern.nyu.edu/adamodar/pdfiles/papers/NewDistress.pdf〉, 16.07.2014.

Hotchkiss, E.S. \& John Kose \& Robert M. Mooradian \& Karin S. Thorburn (2008), "Bankruptcy and The Resolution of Financial Distress", Chapter 14, Handbook of Empricial Corporate Finance, Volume 2, <http://mba.tuck.dartmouth.edu/pages/faculty/karin.thorburn/publications/ch14n53090.pdf $>$, 16.07.2014.

Janes, Troy D. (2003), “Accruals, Financial Distress, and Debt Covenants”, University of Michigan Business School, $<$ http://www1.american.edu/academic.depts/ksb/finance_realestate/mrobe/Seminar/Janes .pdf>, 16.07.2014.

Kahl, Matthias (2002), "Economic Distress, Financial Distress and Dynamic Equation”, The Journal of Finance, Vol. LVII, No. 1, February, <http://web.cenet.org.cn/upfile/97201.pdf>, 16.07.2014.

Mahdi, Salehi \& Bizhan Abedini (2009), "Financial Distress Prediction in Emerging Market: Empirical Evidences from Iran”, Business Intelligence Journal, August, 2009 Vol. 2, No. 2, <http://www.saycocorporativo.com/saycoUK/BIJ/journal/Vol2No2/article10.pdf>, 16.07.2014.

Outecheva, Natalia (2007), "Corporate Financial Distress: An Empirical Analysis of Distress Risk", Dissertation no. 3430, the University of St.Gallen Graduate School of Business Administration, Economics, Law and Social Sciences (HSG), <http://www1.unisg.ch/www/edis.nsf/SysLkpByIdentifier/3430/\$FILE/dis3430.pdf>, 16.07.2014.

Platt, Harlan D. \& Marjorie B. Platt (2008), "Financial Distress Comparison Across Three Global Regions.”, Journal of Risk and Financial Management, No: 1, 129-162, <http://www.mdpi.com/1911-8074/1/1/129>, 16.07.2014.

Platt, Harlan D. \& Marjorie B. Platt (2006), "Understanding Differences Between Financial Distress and Bankrupcty", Review of Applied Economics, Vol. 2, No. 2: 141-157, <http://www.lincoln.ac.nz/Documents/Commerce/RAE/2006\%20I/1Harlan\%20D\%20Platt.pdf>, 16.07.2014.

Pindado, Julio \& Luis Rodrigues (2005), "Determinants of Financial Distress Costs", Swiss Society for Financial Market Research, Financial Markets and Portfolio Management, V.19, N.4., 343-359. 
Poyraz, E. \& S. Didin (2008), “Finansal Hizmetler Sektörü’nde Finansal Başarısızlık Riskinin Altman Finansal Analiz Sistemi Yardımıyla Ölçülmesi", <bandirma.balikesir.edu.tr/bildiriler/17_Erkan_POYRAZ_Saliha_DIDIN.doc $\rightarrow$, 16.07.2014.

Sarlija, Natasha \& Marina Jeger (2011), “Comparing Financial Distress Prediction Models Before And During Recession”, Croatian Operational Research Review (CRORR), Vol. 2. <http://hrcak.srce.hr/96658?lang=en>, 16.07.2014.

Sayılgan, Güven (2008), Işsletme Finansmanı, Turhan Kitabevi, Ankara.

Senbet Lemma, W. \& Tracy Yue Wang (2012), "Corporate Financial Distress and Bankrupcty: A Survey", Foundations and Trends In Finance, July, <http://www.tc.umn.edu/ wangx684/assets/documents/research/Corporate-FinancialDistress-and-Bankruptcy.pdf $>, 16.07 .2014$.

Sormunen, Nina \& Teija Laitinen (2012), "Late financial distress process stages and financial ratios: Evidence for auditors' goingconcern evaluation”, Liiketaloudellinen Aikakauskirja, No. 1, 2012, 41-69, <http://lta.hse.fi/2012/1/lta_2012_01_a2.pdf>, 16.07.2014.

Suarez, Javier \& Oren Sussman (2004), "Financial distress, bankruptcy law and the business cycle", OFRC Working Papers Series, 2004fe07, Oxford Financial Research Centre. 
İhsan KULALI 